\title{
The Flower of Service Concept and Its Influence on the Customer Satisfaction: Case Study of Jordanian Private Hospitals Sector
}

\author{
Tareq N. Hashem ${ }^{1}$ \\ ${ }^{1}$ Marketing Department, Isra University, Amman, Jordan \\ Correspondence: Tareq N. Hashem, Marketing Department, Isra University, Amman, Jordan. E-mail: \\ tareqhashem1975@yahoo.com \\ Received: October 19, 2017 \\ Accepted: December 19, 2017 \\ Online Published: January 15, 2018 \\ doi:10.5539/ijbm.v13n2p122 \\ URL: https://doi.org/10.5539/ijbm.v13n2p122
}

\begin{abstract}
Service and service quality is becoming the hottest topics within the institutions and organizations that present services to their customers regardless of their orientation and field of interest. Generally speaking, services appear as core services which are the basic benefit that a customer gets from purchasing a certain item/service and supplementary services which are the non-routine services that follow the process of acquiring the item/service. Through the literature there appeared an interest in caring for the level of core services on the expense of supplementary services. In that sense, the current study aimed at examining the influence of 'flower of service' dimensions-as supplementary service dimensions-on customer satisfaction within the private hospitals and healthcare givers in Jordan. The sample of the study consisted of (431) individuals who are benefiting from services of private hospitals. A self-administered questionnaire was distributed on the sample which consisted of questions regarding the service quality within the private hospitals in Jordan based on the dimensions of 'flower of service'. The results of the study indicated that the dimensions of the flower of services appeared to be influential on the satisfaction of customers which included (Information, Order Taking, Consultation, Hospitality, Billing Payment) while two dimensions were found to be not influential (Exception , Safe Keeping). It was recommended through the study that the management should increase the awareness among its employees of the difference between the supplementary service and the core service and how each one of them is important in its own way. In addition to that, there should be extra care about the importance of service quality which can take place through the awareness that can be spread through the quality control department. Also, it was recommended that -based on respondents' opinion - to increase the level of hospitality within the private hospitals and present more effective payment solutions for patients and their families considering that a person is mainly waiting to be charged in accordance with the service that they get.
\end{abstract}

Keywords: flower of service, service, customer satisfaction, service quality, healthcare

\section{Introduction}

The concept of service and service quality has been the focus of many scholars and researcher through the last few years of the $20^{\text {th }}$ century till the present time. There have been many indicators that gathered between the idea of service that is presented to customers, its quality and the satisfaction of customers towards the presented services (Lewis \& Mitchell, 1990). The significance of service quality as a marker of customer satisfaction and organizational performance is broadly recognized and has prompted a noteworthy research push which has concentrated on various ventures inside the service sector. A portion of the exploration identifying with characterizing and measuring service quality is assessed and various proposals are made in the matter of how estimation instruments, for example, SERVQUAL may be progressed.

Currently individuals live in a situation that is progressively moving towards a service-based economy. Different services are not parts of the economy, but rather are considered as the core of significant worth creation in economy. Because of the expanding part of service organizations in the regions of the economy and the significance of value in the territories of competition, service organizations must hope to benefit quality service management with dynamic and key approach and have a reasonable comprehension of the quality status of management, the desires of the customer (client) and the general attributes of their quality. Service with respects contrasted with merchandise are elusive and are viewed as a vital part of service providers, hence their evaluation by their clients are more troublesome (Nejadjavad \& Gilaninia, 2016). 


\section{Problem Statement}

According to Kumar, Maniunath and Chethan (2012) quality is considered as one of the essential factors in excellence and differentiation of service and it is a premise of upper hand with the goal that its understanding, measuring, and creating it are vital difficulties for all health services organizations. Zaim, Bayyurt and Zaim (2010) on the other hand saw that there is a strong relationship between the concept of service quality and the eligibility of the healthcare services and the performance of its organization to the customer satisfaction. Service quality is an essential bearing for upgrading business performance specifically in the healthcare systems and sectors, which underlies the boundless reception of value change activities in many service providers. Service quality changes for accomplishing client desires (customer satisfaction) and fulfillment has turned into a noteworthy test for services within healthcare sector given that this sector is one of the most influenced sector by the satisfaction and loyalty of customers (Punnakitikashem et al, 2012).

Based on that, the current research aims at examining the influence of applying the flower of service model by Christopher Lovelock (1996) within the Jordanian private hospitals sector. The idea revolves around understanding to what extent may the application of the flower of service may influence the satisfaction of customers towards the services presented by the private hospitals in Jordan and do the dimensions of the model has an influence on their satisfaction?

\section{Review of the Literature}

\subsection{Service Marketing and Management}

According to Nejadjavad and Gilaninia (2016) service and service quality has turned into an exceptionally interesting issue in service marketing and management (SMM), operation management (OR) and design research. Service quality is as of now rising as one of the significant subjects of the current business and plan instruction. The causes for service quality can be found in management and marketing literature. Because of fast development and substantial rivalry in service business in western world management has put on more weight in the research field. While the term service quality was delivered by service marketing specialists it increased substantially more energy when the design of the service began to demonstrate enthusiasm for it. Albeit all players are heading into same course and generally appear to utilize fundamentally the same as way to deal with service quality some incredible contrasts appear to exist. The dialog appears to converging from single orders into multidisciplinary Service Science. This is making transitory motion of definitions, methodologies and dialects until more exhaustive vocabulary for service quality, service marketing and service management began to establish.

\subsection{Service Definition}

There appeared many definitions for service, many scholars have come to present their own perspective of the term service, however, those definitions came to cross each other and lead to the same area of interest which is (customer oriented). The American Society for Marketing (2008) defined service as the set of benefits and activities that are bound for sale or that are related to a particular item or product. Kotler (2003) on the other hand defined service as the behavior that results from the contact between the provider of the service and the receiver (customer) while Gummesson (2004) saw that service is the characteristics, properties and features of the service that ends up in satisfying the customer and meet their expectations. Going through the definitions of service which were provided by many scholars it appeared that the end result of the idea of service is bound to the concept of customer satisfaction and customer loyalty, in another meaning, one can see through the definition that the core idea of service revolves around reaching the best and most accurate level of customer satisfaction through increasing the quality of the service based on the performance of the organization leading to a better satisfaction and an increased level of competitive advantage and market share.

\subsection{Flower of Service}

There appeared through the literature many orientations and types for the idea of service, among them is the concept of supplementary service which refers to the secondary services which are presented to the customers after the acquisition of the item/service/product. According to Goyal (2004) when it comes to service; there are two types of services, the core service which refers to the results and consequences of purchasing a certain item that a customer expects for the charges of the item, like for example when a customer purchases an answering machine the end used (customer) expects from the machine to take messages and store them; on the other hand there is the other type of service which is the supplementary service referring to the group of services which either facilitates or enhance the use of the core services (Lovelock \& Wirtz, 2016).

Service providers often seek to offer to their customers a comprehensive experience with the aim of motivating 
them to engage in future purchases and to cement customer loyalty. To achieve these, service providers supplement core services with supplementary services. These supplementary and core services can help a company to increase client satisfaction and improved their services. They are collectively captured referred in the flower of service model.

This comprehensive model recognizes two kinds of services that an organization should offer to customers: core service and supplementary service. The core products are the commodities and central components that provide the principal problem-solving benefits that are sought by customers. These products are augmented by supplementary services. These supplementary services facilitate the use of the core services and enhance their appeal and value enabling the company to charge a premium price. The core and supplementary services are delivered using the delivery processes (Storey \& Easingwood, 1998; Lovelock, 1992; Bitner, Brown \&Meuter, 2000). In this case, supplementary services are categorized into two: enhancing supplementary services and facilitating supplementary services (Lovelock, Patterson, \& Chew, 2009). Supplementary services, supporting, or enhancing include safekeeping, consultation, expectations, and hospitality.

On the other hand, facilitating supplementary services include payment, billing, order-taking, and information. These elements facilitate the use of core product and enhance service delivery (Lovelock, Patterson, \& Chew, 2009). These elements also assist the company to differentiate from competitors by adding value to the service (Lovelock, Patterson, \& Chew, 2009). As acknowledged that while the core service is undifferentiated, the "provided products", which consist of supplementary services are differentiable and make a difference between the failure and success in a competitive marketplace. Lastly, service delivery which facilitate the delivery of the supplementary and core product/service help in clarifying service/product elements. It can be used to distinguish between supplementary products and the service product. This service also helps the management to visualize the total service experience of the customer.

\subsection{Supplementary Services}

Over thirty years ago, Levitt (1980) indicated recognized the importance of supplementary services by emphasizing that in a competitive marketplace, supplementary services will create a difference between a firm that succeeds and one that fails. This study recognized that supplementary services may profoundly impact on customer value by enhancing their appeal and value enabling the company to charge a premium price. However, this study did not provide the structure that could enable companies to identify specific elements that help increase value of the core product. Lovelock $(1992 ; 1995)$ addressed this issue by developing a supplementary service model that offers specific guidelines through which customer value could be enhanced. This model showed how the core service could be augmented by additional services. It categorized supplementary services into two: supporting products/services and facilitating services. The former are supplementary, augmented or additional products or services that enable the company to differentiate its products from services of the competitor. These services add value to the company's core products/services. They combine with the company's core products supporting and facilitating products/services to offer augmented services/products. Examples of these products include the atmosphere, accessibility, interaction among customers, customer participation, and customer interaction with the organization's services (Kotler, Bowen \&Makens, 2010). The latter are products or services that facilitate the use of the core services and enhance their appeal and value enabling the company to charge a premium price. These services support the core products and should be available for the client to use the core service/product (Kotler, Bowen \&Makens, 2010). Lovelock's model further classified supplementary services into eight clusters: payment, consultation, safekeeping, information, billing, order-taking, exceptions and hospitality (Lovelock, 1992; 1995). This model offers a structured approach to analyzing the augmented and core services in a service organization.

\subsection{Information}

Information is a facilitating supplementary service that is needed by customers for service delivery (Lovelock, Patterson, \&Wirz, 2011). It provides guidance and understanding of the usage of core products, conditions of sales; pricing etc. without it, customers will be left unsure. Customer may also require important information such as information or how to use or obtain a service or product. Examples of elements information on usage instructions, prices, direction to service site, conditions of sale, service/schedule hours, warnings, confirmation of reservations, documentation, notification of changes, and reminders.

\subsection{Order Taking}

Customer may want to be informed about what may be available and secure commitment to delivery. It is important to make the process smooth and fast. The company's order-taking should also be accurate, fast and polite to enable customer to endure unnecessary physical or mental effort and not to waste time (Lovelock, Patterson, 
\&Wirz, 2011). Companies require prospective clients to enable their customers to successfully go through the application process aimed at collecting relevant information and identify those customers who with serious health problems or bad credit records and do not meet the criteria for enrollment. Some firms require prospective clients to make application in order to be considered. Reservations notably check-in and appointments are a special form of order-taking which entitles clients to specific units of service at a given location and time for example, a hotel room, admission to a facility, a restaurant table or an airline seat. Examples of elements include order entry, applications, check-in and reservations, vehicle or equipment rental, memberships in programs/clubs, order entry, prerequisite based services (college enrollment, financial credit), telephone/mail/web order reservations, on-site order fulfillment, seats/rooms/tables, and professional appointments.

\subsection{Consultation}

Consultation is an enhancing supplementary service. It enhances service delivery by adding value and making it more appealing to clients. These services may include personal counseling and customized advice. They purchase the company's expertise and knowledge. As noted by Naipaul, and Parsa (2000), consultation and advice that are tailored to the needs of the situation and needs of customers can add value to the company's services and goods. Examples of elements include management or technical consulting, personal counseling and customized advice, and training/tutoring on the use of the product

\subsection{Hospitality}

The business need to treat customers who invest effort and time to visit the business and use it services should be handled with hospitality it deserves. Hospitality is an enhancing supplementary service. It enhances service delivery by adding value to the firm's products and services and making them more appealing to clients. Hospitality-related services need to reflect pleasure to greet old clients when they come back and meeting new ones. These services should be designed to welcome to welcome new customers. Well-managed companies invest in ensuring that employees treat clients with courtesy and as guests. Consideration for needs of clients should apply to telephone interactions as well as to face-to-face encounters. Hospitality begins from the service site and the offer of transport. It includes offering refreshments, creating comfortable waiting areas, cleaning toilets, and making customers to feel welcome. Other elements that enhance hospitality include offering drinks (food and beverages), security, greeting, toilets and washrooms, and waiting facilities and amenities, weather protection, seating, lounges, waiting areas, security, transport, and entertainment, newspapers and magazine (Lovelock, Patterson, \&Wirz, 2011). The quality of the hospitality services of a company may decrease or increase the customer satisfaction with its core service or product. This is applied to people-processing services that involve people leaving the service facility.

\subsection{Safe Keeping}

Customers visiting a service site will want to be assisted with personal possessions. Unless the company provides safekeeping services like convenient and safe car packaging), these customers may cease to come. Safekeeping involves keeping records for the clients safely, private and confidential. Like hospitality, safekeeping is an enhancing supplementary service. It enhances service delivery by adding value to the firm's products and services and making them more appealing to clients. Safe keeping increases customer trust in the company and its staff. The company must look after client's personal possessions (Lovelock, Patterson, \&Wirz, 2011). The list of safekeeping services range from safe keeping include caring for goods rented or purchased by clients, looking after customers' possessions to caring for goods rented or purchased by clients. Caring for customers' possessions may be include baggage handling, child care, parking for vehicles, pet care, storage space, security personnel (security staff), safe deposit boxes and coat rooms. Caring for goods rented or purchased by customers may be achieved by providing the following services: repair and renovation, preventive maintenance, transportation and delivery, packaging, installation, pickup and inspection and diagnosis. Others may include provision of coatrooms, leaning and inspection (Naipaul \&Parsa, 2000).

\subsection{Exceptions}

Exceptions are non-routine supplementary services that are not part of the normal service delivery. Well-defined procedures enable employees to respond effectively and promptly (Naipaul, \&Parsa, 2000). Customers expect responsiveness whenever things seem not to work according to the plan and appreciate flexibility in cases where they want to be allowed to make special request. Examples of elements include restitution, compliments or complaints, special request in advance, problem solving, resolving difficulties arising from the use of products, guarantees and warranties, compensation and refunds, assisting clients who suffer a medical emergency or accident, resolving difficulties arising from service failures or accidents, and free repair of client's defective goods (Lovelock, Patterson, \&Wirz, 2011). Special requests are made by customers who many want to depart from the 
company's normal operating procedures. They can make advance requests relating to personal needs such as dietary requirements, personal disabilities, childcare, or religious observances (Goyal, 2004). Problem-solving situations arise due to the failure of normal product performance or service delivery to run smoothly. This may be caused by equipment failure, delays, accidents or clients experiencing challenges with the use of the service or product. Handling of suggestions, compliments or complaints require well-defined procedures. The company should make it easy for customers to offer suggestions for improvement, express dissatisfaction, or pass compliments to service providers. Restitution are compensations to customers for serious performance failures. These may take the form of legal settlements, respires under warranty, or offers for free service (Hume, 2008).

\subsection{Billing}

Bills should be accurate clear and intelligible to customers. Example of elements related to bills include machine display of required amount; periodic statement of the activity of the account; self-billing (computed by clients), and invoices for individual transactions (Hume, 2008).Billing is a common supplementary service almost all services especially for paid services. Incomplete, illegible or inaccurate bill may disappoint customers who may be satisfied with the service or experience. These failures may compound the injury for clients who are already dissatisfied with the service. Billing procedures may range from machine-displayed price, to verbal statements, from monthly statements of fees and account activity to handwritten invoices (Hume, 2008). Recent technological advances have enabled companies to adopt computerized billing. It is important to note that these computerized forms of billing can also cause service failures and lead to overbilling the customer. Customers often expect clear and informative bills and those that have been itemized in a way that make possible for them to know how the totals were computed. Confusing and unexpected charges, illegible handwriting and fuzzy printing may create poor impression to the customer (Naipaul \&Parsa, 2000). Laser printers that lack the capability to typefaces and switch fonts may produce illegible statements. Companies should therefore, focus on designing user-friendly bills based on what the customers want as billing information can help a company to offer an added value to customers.

\subsection{Payment}

Like information, payment/invoicing are a facilitating supplementary service that is needed by customers for service delivery. Customers want to know what they pay for, how to pay and when they need to pay. This can be facilitated by clear, accurate and on-time invoice. Customer can pay more cheerfully and faster if a company makes transaction more convenient and simple for them. Examples of elements include automation deduction, direct to payee or self-service payment, insert card, entering credit card number directly online to intermediary or payee, electronic funds transfer, cash or token into machine, change giving or cash handling, and improvement of voucher automation deductions from financial deposits (Lovelock, Patterson, \&Wirz, 2011).

In a number of cases, customers will be required to take action with regard to payment. Customers often expect convenient payment when making purchases. Customers bill paying can be facilitated in many ways: self-service payment system, hand-to-hand transfer of checks and cash, debit and credit card payment, prepaid tickets, coupons, vouchers or tokes. Self-service payment system require clients to insert cards, tokes, coins or banknotes in machines. However, the breakdown of machines can destroy the system. Still some payment are made via hand-to-hand transfer of checks and cash. However, the use of debit cards and credit cards is the most established form of payment.

\subsection{Flower of Service Application in Healthcare Systems}

Studies have demonstrated that the flower of service model can be applied in various service firms namely tourism sector (Naipaul \&Parsa, 2000); retailers and financial sector (Colgate \& Alexander, 2002); banks' credit card services (Goyal, 2004); performing arts (Hume, 2008). Naipaul and Parsa (2000) examined the applicability of supplementary services model in the tourism sector. However, Naipaul and Parsa (2000) did not focus on all the eight cluster of supplementary services rather focus only one cluster. In another study, Goyal (2004) investigated the application of 13 supplementary service in the banks' credit card services. However, it is unclear how the researcher identified these supplementary services. More revealing is that none of these studies have examine the applicability of the flower of service within the healthcare sector. However, it is acknowledged that this model can be applied in healthcare sector. For example, within the context of flower of service, services provided in the hospitals can be categorized into core and supplementary services as follow. Core services may include diagnostic and treatment services offered by doctors. On the other hand, supplementary services in hospitals may include Billing and Insurance Services; Facility \& Maintenance; Food \& Beverage; Dietary Services; House Keeping Services; Operations \& Administration and Nursing Services. These services are the differentiators for hospitals and helps in defining the level of service that should be offered to clients based on their level of willingness to pay for services. It is through these supplementary services that hospitals earn premiums. These services are offered 
alongside core medical services.

\section{Methodology}

The following section presented the methodological scheme which was followed in building the current research study, the way the raw data was collected and how the researcher will deal with the raw data in order to change it into acceptable and understandable set of results in accordance with the previously presented hypotheses and objectives.

\section{Method}

In order to achieve the objectives of the study, the researcher has chosen to employ the quantitative approach in realizing the hypotheses of the study and answering its questions. Sukamolson (2006) defined quantitative approach as "The numerical representation and manipulation of observations for the purpose of describing and explaining the phenomena that those observations reflect" (p.2). So based on that, the quantitative approach is normally deductive and it is "a valid reasoning by which it is impossible to accept the premises but reject the conclusion" as according to Zalaghi and Khazaei (2016); (Borrego, Douglas, \& Amelink, 2009).

The researcher has chosen the questionnaire to be the tool of the study. The questionnaire constituted to two main parts, the first part was the demographic variable which takes into account the demographic information of the sample of the study, and the second paragraph which was questions regarding the variables of 'flower of service'. The used scale in the current research study was Liker 5 scale on which the answers of the sample of the study were based on (strongly agree 5 - agree 4 - neutral 3 - disagree 2 - strongly disagree 1 ).

\section{Populations and Sample}

The population of the study consisted of individuals who benefit from the services of the private hospitals in Jordan. A convenient sample of study was set to be initially (500) individual from different private hospitals and healthcare givers in Jordan. The total sample which responded to the questionnaire reached in its final version to (431) respondent which means that the response rate was $86.2 \%$ which is a statistically acceptable response rate.

\section{Questions of the Study}

Mainly, the current study is a try to answer the following questions:

1- What is the influence of applying flower of service dimensions as supplementary services on the satisfaction of customers?

2- Do private hospitals and healthcare givers in Jordan enjoy the characteristics of service quality?

3- To what extent respondents saw that private hospitals and healthcare givers in Jordan are aware of the concept of service quality?

\section{Main Hypothesis}

There is a statistically significant influence of applying flower of service on customer satisfaction within the private hospitals in Jordan

\section{Sub-Hypotheses:}

$\mathbf{H}_{\mathbf{0}}$ 1: There is no statistically significant influence of information on customer satisfaction within the private hospitals in Jordan

$\mathbf{H}_{0}$ 2: There is no statistically significant influence of order taking on customer satisfaction within the private hospitals in Jordan

$\mathbf{H}_{0}$ 3: There is no statistically significant influence of consultation on customer satisfaction within the private hospitals in Jordan

$\mathbf{H}_{\mathbf{0}} \mathbf{4}$ : There is no statistically significant influence of hospitality on customer satisfaction within the private hospitals in Jordan

$\mathbf{H}_{\mathbf{0}}$ 5: There is no statistically significant influence of safe keeping on customer satisfaction within the private hospitals in Jordan

$\mathbf{H}_{\mathbf{0}} \mathbf{6}$ : There is no statistically significant influence of exceptions on customer satisfaction within the private hospitals in Jordan

$\mathbf{H}_{\mathbf{0}}$ 7: There is no statistically significant influence of billing on customer satisfaction within the private hospitals in Jordan

$\mathbf{H}_{\mathbf{0}}$ 8: There is no statistically significant influence of payment on customer satisfaction within the private 
hospitals in Jordan

\section{Model of the Study}

\section{Flower of service dimensions}

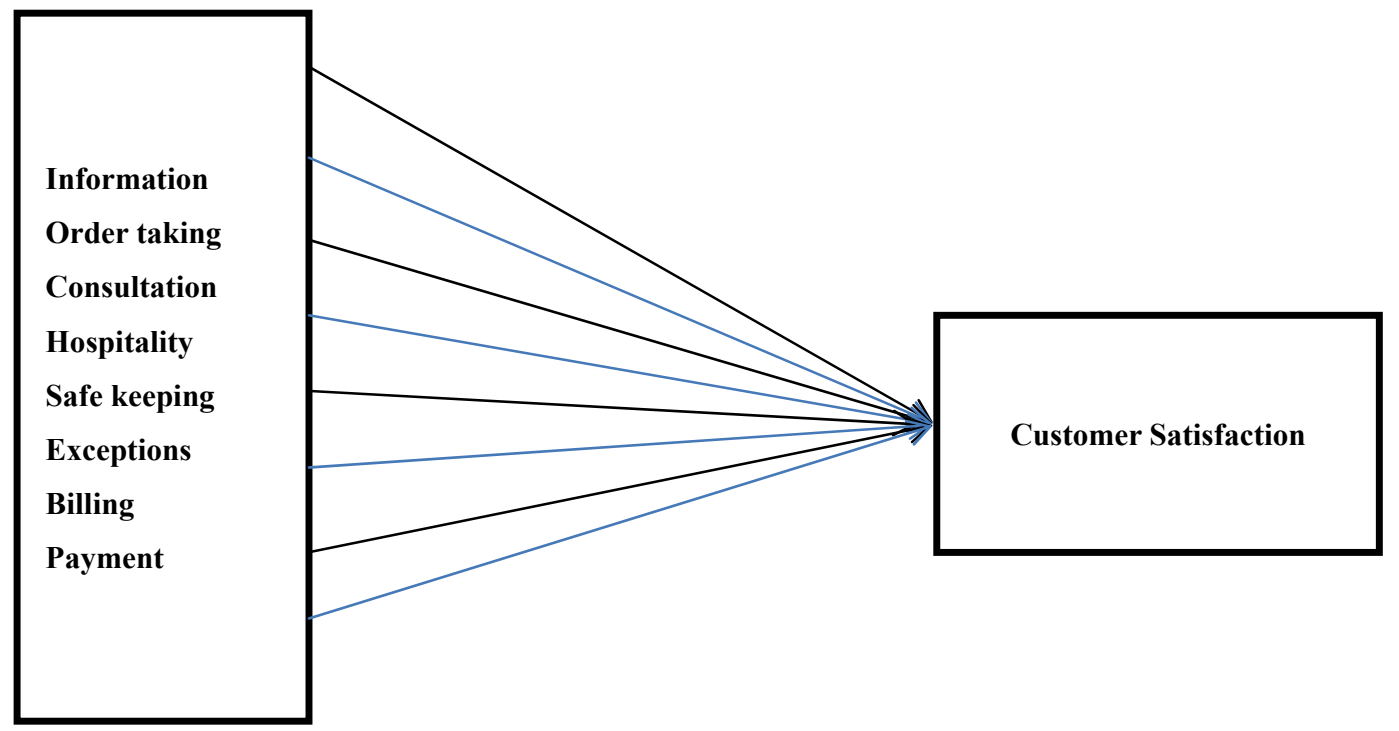

Figure 1. Study Model

\section{Results}

The current section presents the demographic analysis of the sample of the study according to the analysis. The demographic variables consisted of (Gender, Occupation and Education).

\subsection{Demographic}

The following section presented the analysis of the study data which were gathered from the sample through the used tool. The section appeared in two parts, the first presented the analysis of the demographic variables while the second presented the analysis of the questionnaire paragraphs.

\subsubsection{Gender}

Table 1. Sample characteristics according to gender

\begin{tabular}{llllll}
\hline & & Frequency & Percent & Valid Percent & Cumulative Percent \\
\hline \multirow{2}{*}{ Valid } & Male & 274 & 63.6 & 63.6 & 63.6 \\
& Female & 157 & 36.4 & 36.4 & 100.0 \\
& Total & 431 & 100.0 & 100.0 & \\
\hline
\end{tabular}

It can be seen according to table 1 above that most of the sample of the study was male individuals with a frequency of 247 and a percentage of $63.6 \%$ compared to the percentage of females $36.4 \%$ which gives an indication that more than half of the sample who responded to the questionnaire were males.

\subsubsection{Educational Level}

Table 2. Sample characteristics according to educational level

\begin{tabular}{llllll}
\hline & Frequency & Percent & Valid Percent & Cumulative Percent \\
\hline Valid & high school or less & 66 & 15.3 & 15.3 & 15.3 \\
& diploma & 140 & 32.5 & 32.5 & 47.8 \\
& Bachelor & 189 & 43.9 & 43.9 & 91.6 \\
Postgraduate studies & 36 & 8.4 & 8.4 & 100.0 \\
& 431 & 100.0 & 100.0 & \\
\hline
\end{tabular}


Table 2 shows that $43.9 \%$ of individuals who answered the questionnaire had a bachelor degree with a frequency of 189 individual followed by individuals who had a diploma with a percentage of $32.5 \%$. The least percentage came for individuals who had postgraduate studies with a percentage of $8.4 \%$. in general, the results indicated that individuals who responded to the questionnaire were educated and had the needed awareness in regard to the core idea of the study.

10.1.3 Occupation

Table 3. Sample characteristics according to occupation

\begin{tabular}{llllll}
\hline & & Frequency & Percent & Valid Percent & Cumulative Percent \\
\hline Valid & Housewife & 139 & 32.3 & 32.3 & 32.3 \\
& Private Employee & 206 & 47.8 & 47.8 & 80.0 \\
& Governmental Employee & 46 & 10.7 & 10.7 & 90.7 \\
& Self-Employed & 40 & 9.3 & 9.3 & 100.0 \\
Total & 431 & 100.0 & 100.0 & \\
\hline
\end{tabular}

Table 3 shows that $47.8 \%$ of individuals who answered the questionnaire were employed in the private sector followed by housewives with a percentage of $32.3 \%$. However, the least percentage came for individuals who were self-employed with a percentage of $9.3 \%$. The results indicated that almost half of the sample was employed in the private sector which is attributed to the fact that the healthcare systems and insurance within the private sector in Jordan is oriented towards the private hospitals and healthcare centers.

10.1.4 Do You Always Choose A Private Hospital For You and Your Family Members?

Table 3. Sample characteristics according to choice of hospital sector

\begin{tabular}{llllll}
\hline & & Frequency & Percent & Valid Percent & Cumulative Percent \\
\hline \multirow{2}{*}{ Valid } & Yes & 431 & 100.0 & 100.0 & 100.0 \\
& No & 0 & 0.00 & 0.00 & \\
\hline
\end{tabular}

10.1.5 Descriptive Analysis of Variables of the Study

Table 4. Descriptive statistics

\begin{tabular}{llllll}
\hline & N & Minimum & Maximum & Mean & Std. Deviation \\
\hline Information & 431 & 1.00 & 5.00 & 3.5147 & .90716 \\
Order Taking & 431 & 1.00 & 5.00 & 3.4455 & .88495 \\
Consultation & 431 & 1.00 & 5.00 & 3.5378 & .90530 \\
Hospitality & 431 & 1.00 & 5.00 & 3.5271 & .91468 \\
Safe Keeping & 431 & 1.00 & 5.00 & 2.4914 & 1.32050 \\
Exception & 431 & 1.00 & 5.00 & 2.3237 & 1.34960 \\
Billing & 431 & 1.00 & 5.00 & 3.5331 & .95946 \\
Payment & 431 & 1.00 & 5.00 & 3.5067 & .92033 \\
Customer Satisfaction & 431 & 1.00 & 5.00 & 3.5522 & .95413 \\
\hline
\end{tabular}

Examining the above table 4, it can be seen that there are negative attitudes toward variables (Safe Keeping \& Exception) because their means are less than mean of the scale (3) whereas there are positive attitudes from participants towards the rest of variables. This appeared through the mean of the paragraphs which scored higher than 3.00 referring to the paragraph as a good indicator. 


\subsection{Variable Analysis}

Table 5. Descriptive Statistics

\begin{tabular}{|c|c|c|c|c|c|}
\hline & $\mathbf{N}$ & Minimum & Maximum & Mean & $\begin{array}{l}\text { Std. } \\
\text { Deviation }\end{array}$ \\
\hline \multicolumn{6}{|l|}{ Flower of Service } \\
\hline \multicolumn{6}{|l|}{ Information } \\
\hline $\begin{array}{l}\text { Information of the hospital can be reached through the leaflets, websites and } \\
\text { the front desk }\end{array}$ & 431 & 1.00 & 5.00 & 3.9814 & 1.13491 \\
\hline The hospital website is satisfactory and contains all the needed information & 431 & 1.00 & 5.00 & 3.3666 & 1.12692 \\
\hline Staff of the hospital always gives information to patients and visitors & 431 & 1.00 & 5.00 & 3.3782 & 1.14257 \\
\hline There are many informative boards on the walls of the hospital & 431 & 1.00 & 5.00 & 3.4733 & 1.14266 \\
\hline Employees are always willing to give information to visitors and patients & 431 & 1.00 & 5.00 & 3.4919 & 1.16112 \\
\hline The hospital operators give information through the phone & 431 & 1.00 & 5.00 & 3.4339 & 1.13493 \\
\hline $\begin{array}{l}\text { There is a representative in the hospital who escorts patients through the } \\
\text { departments of the hospital }\end{array}$ & 431 & 1.00 & 5.00 & 3.4780 & 1.10553 \\
\hline \multicolumn{6}{|l|}{ Order Taking } \\
\hline Employees are always ready to help & 431 & 1.00 & 5.00 & 3.1856 & 1.12390 \\
\hline $\begin{array}{l}\text { The registry of the hospital takes the patients' information as soon as they } \\
\text { check in }\end{array}$ & 431 & 1.00 & 5.00 & 3.3921 & 1.09834 \\
\hline Errors are rare when it comes to patients' information & 431 & 1.00 & 5.00 & 3.3805 & 1.13874 \\
\hline The nursing staff is always ready to help & 431 & 1.00 & 5.00 & 3.6821 & 1.16485 \\
\hline The night shift nurses answers directly to the night call button & 431 & 1.00 & 5.00 & 3.4919 & 1.10572 \\
\hline The room service at the hospital are always ready to take orders & 431 & 1.00 & 5.00 & 3.5406 & 1.11339 \\
\hline \multicolumn{6}{|l|}{ Consultation } \\
\hline Doctors are available $24 / 7$ & 431 & 1.00 & 5.00 & 3.4965 & 1.10994 \\
\hline There is an alternate physician to every department through the night shifts & 431 & 1.00 & 5.00 & 3.5708 & 1.14282 \\
\hline $\begin{array}{l}\text { There is a soft copy of the patients' file on every related doctor's hospital } \\
\text { account }\end{array}$ & 431 & 1.00 & 5.00 & 3.4872 & 1.10146 \\
\hline Related doctors are always aware of the patient's case & 431 & 1.00 & 5.00 & 3.4756 & 1.10758 \\
\hline There is always a physician to consult anytime of the day & 431 & 1.00 & 5.00 & 3.6589 & 1.08141 \\
\hline \multicolumn{6}{|l|}{ Hospitality } \\
\hline Staff are welcoming & 431 & 1.00 & 5.00 & 3.3944 & 1.08793 \\
\hline Staff enjoys a good level of courtesy & 431 & 1.00 & 5.00 & 3.4455 & 1.09169 \\
\hline Employees give their best to help patients and visitors & 431 & 1.00 & 5.00 & 3.4640 & 1.11771 \\
\hline The management makes sure to give the best experience to the patients & 431 & 1.00 & 5.00 & 3.5406 & 1.15037 \\
\hline There is a good level of understanding among employees & 431 & 1.00 & 5.00 & 3.7912 & 1.20001 \\
\hline \multicolumn{6}{|l|}{ Safe Keeping } \\
\hline Files and registrations are located within the department & 431 & 1.00 & 5.00 & 2.6381 & 1.51699 \\
\hline No one is allowed to check the file of the patient outside of the hospital & 431 & 1.00 & 5.00 & 2.4130 & 1.46151 \\
\hline $\begin{array}{l}\text { Information about the patients are given only to the related individuals who } \\
\text { are following the case }\end{array}$ & 431 & 1.00 & 5.00 & 2.6102 & 1.48678 \\
\hline $\begin{array}{l}\text { The security outside the hospital checks every individual who enters the } \\
\text { hospital }\end{array}$ & 431 & 1.00 & 5.00 & 2.4408 & 1.39621 \\
\hline Staff don't share the information of the patients & 431 & 1.00 & 5.00 & 2.3550 & 1.27652 \\
\hline \multicolumn{6}{|l|}{ Exceptions } \\
\hline The hospital matches the requirements of a private hospital & 431 & 1.00 & 5.00 & 2.0719 & 1.23963 \\
\hline Cleanliness and hygiene is very good & 431 & 1.00 & 5.00 & 2.2993 & 1.43575 \\
\hline Staff is always wearing the uniform of the hospital & 431 & 1.00 & 5.00 & 2.4316 & 1.52020 \\
\hline The services of the hospital is very expensive compared to other hospitals & 431 & 1.00 & 5.00 & 2.3480 & 1.55054 \\
\hline The parking lots are wide enough and there is always a place to park & 431 & 1.00 & 5.00 & 2.3248 & 1.53451 \\
\hline Cleanliness and Hygiene is poor for a hospital & 431 & 1.00 & 5.00 & 2.4664 & 1.52137 \\
\hline \multicolumn{6}{|l|}{ Billing } \\
\hline The hospital issues the bill as soon as the related doctor releases the patient & 431 & 1.00 & 5.00 & 3.5684 & 1.15510 \\
\hline The hospital makes communications with the insurance company in case there & 431 & 1.00 & 5.00 & 3.4756 & 1.13249 \\
\hline
\end{tabular}




\begin{tabular}{|c|c|c|c|c|c|}
\hline \multicolumn{6}{|l|}{ appeared a mistake } \\
\hline The hospital makes discounts for relatives and families of its staff & 431 & 1.00 & 5.00 & 3.6288 & 1.12746 \\
\hline $\begin{array}{l}\text { The hospital communicates with a certain individual who is related to the } \\
\text { patient when it comes to financial issues }\end{array}$ & 431 & 1.00 & 5.00 & 3.4594 & 1.06862 \\
\hline \multicolumn{6}{|l|}{ Payment } \\
\hline There an installment plans for large bills & 431 & 1.00 & 5.00 & 3.4107 & 1.09790 \\
\hline The hospital takes credit cards service for payment & 431 & 1.00 & 5.00 & 3.3225 & 1.12081 \\
\hline The hospital accepts more than currency for payment & 431 & 1.00 & 5.00 & 3.4640 & 1.11563 \\
\hline The hospital accepts checks & 431 & 1.00 & 5.00 & 3.5406 & 1.14835 \\
\hline The hospital accepts delays in payments based on personal guarantees & 431 & 1.00 & 5.00 & 3.7958 & 1.20274 \\
\hline \multicolumn{6}{|l|}{ Customer Satisfaction } \\
\hline The service at the hospital satisfies my needs & 431 & 1.00 & 5.00 & 3.4571 & 1.12576 \\
\hline If I am not happy with the service I get I don't come back & 431 & 1.00 & 5.00 & 3.3759 & 1.14639 \\
\hline I care about the reputation of the hospital & 431 & 1.00 & 5.00 & 3.5081 & 1.14091 \\
\hline I don't pay attention to the minute details & 431 & 1.00 & 5.00 & 3.5870 & 1.16588 \\
\hline My satisfaction is the success of the hospital & 431 & 1.00 & 5.00 & 3.8329 & 1.21039 \\
\hline
\end{tabular}

Examining the above table 5, it can be seen that there are negative attitudes towards the paragraphs which are under the variables of (safekeeping and exceptions) because their means are less than mean of the scale(3) whereas there are positive attitudes from participants towards the rest of questions. This appeared through the mean of the paragraphs which scored higher than 3.00 referring to the paragraph as a good indicator.

10.3 Reliability Test

A reliability test was carried out using Cronbachs' alpha, The result showed a value of (0.963) for the all items as well as alpha for each variable is greater than accepted percent 0.60 , which is a reasonable value indicating the tool consistency that enhanced its use for the study

\subsection{Hypotheses Testing}

Main Hypothesis: There is a statistically significant influence of applying flower of service on customer satisfaction within the private hospitals in Jordan.

Table 6. Model summary

\begin{tabular}{lllll}
\hline Model & R & R Square & Adjusted R Square & Std. Error of the Estimate \\
\hline 1 & $.962^{\mathrm{a}}$ & .926 & .924 & .26265 \\
\hline
\end{tabular}

Table 7. ANOVA ${ }^{\mathrm{a}}$

\begin{tabular}{lllllll}
\hline Model & & Sum of Squares & df & Mean Square & F & Sig. \\
\hline 1 & Regression & 362.343 & 8 & 45.293 & 656.541 & $.000^{\mathrm{b}}$ \\
& Residual & 29.113 & 422 & .069 & & \\
& Total & 391.455 & 430 & & & \\
\hline
\end{tabular}

Multiple regression was used to test this hypothesis, It was found that $\mathrm{R}(0.962)$ is the correlation of the independent variables and the dependent variable. Also it was found that the $\mathrm{F}$ value of $(656.541)$ is significant at $(0.05)$ level. Thus, there is a statistically significant influence of applying flower of service on customer satisfaction within the private hospitals in Jordan.

The following presented the testing of the sub-hypotheses:

$H_{0} 1$ : There is no statistically significant influence of information on customer satisfaction within the private hospitals in Jordan. 
Table 8. Model Summary

\begin{tabular}{lllll}
\hline Model & R & R Square & Adjusted R Square & Std. Error of the Estimate \\
\hline 1 & $.766^{\mathrm{a}}$ & .586 & .585 & .61451
\end{tabular}

a. Predictors: (Constant), Information

Table 9. Coefficients ${ }^{\mathrm{a}}$

\begin{tabular}{lllllll}
\hline \multirow{2}{*}{ Model } & \multicolumn{2}{l}{ Unstandardized Coefficients } & \multicolumn{2}{l}{$\begin{array}{l}\text { Standardized Coefficients } \\
\text { Beta }\end{array}$} & t & Sig. \\
& $\mathrm{B}$ & Std. Error & Ber & & \\
\hline 1 & (Constant) & .722 & .119 & .766 & 6.089 & .000 \\
& Information & .805 & .033 & 24.650 & .000 \\
\hline
\end{tabular}

Linear regression was used to test this hypothesis; it was found that $\mathrm{R}(0.766)$ is the correlation of the independent variable and the dependent variable. Also it was found that the t value of (24.65) is significant at $(0.05)$ level. Thus, there is a statistically significant influence of information on customer satisfaction within the private hospitals in Jordan

$\mathrm{H}_{0}$ 2: There is no statistically significant influence of order taking on customer satisfaction within the private hospitals in Jordan.

Table 10. Model summary

\begin{tabular}{|c|c|c|c|c|}
\hline Model & $\mathrm{R}$ & $\begin{array}{l}\mathrm{R} \\
\text { Square }\end{array}$ & $\begin{array}{l}\text { Adjusted R } \\
\text { Square }\end{array}$ & $\begin{array}{l}\text { Std. Error of } \\
\text { the Estimate }\end{array}$ \\
\hline 1 & $.777^{\mathrm{a}}$ & .603 & .602 & .60175 \\
\hline
\end{tabular}

a. Predictors: (Constant), Order Taking

Table 11. Coefficients ${ }^{\mathrm{a}}$

\begin{tabular}{|c|c|c|c|c|c|c|}
\hline \multirow[t]{2}{*}{ Model } & & \multicolumn{2}{|c|}{$\begin{array}{l}\text { Unstandardized } \\
\text { Coefficients }\end{array}$} & \multirow{2}{*}{$\begin{array}{l}\text { Standardize } \\
\text { d } \\
\text { Coefficients } \\
\text { Beta } \\
\end{array}$} & \multirow[t]{2}{*}{$\mathrm{t}$} & \multirow[t]{2}{*}{ Sig. } \\
\hline & & $\mathrm{B}$ & Std. Error & & & \\
\hline \multirow[t]{2}{*}{1} & (Constant) & .667 & .117 & & 5.719 & .000 \\
\hline & $\begin{array}{l}\text { Order } \\
\text { Taking }\end{array}$ & .837 & .033 & .777 & 25.536 & .000 \\
\hline
\end{tabular}

Linear regression was used to test this hypothesis;itwasfound that $\mathrm{R}(0.777)$ is the correlation of the independent variable and the dependent variable. Also it was found that thet value of (25.536) is significant at (0.05) level. Thus, there is a statistically significant influence of order taking on customer satisfaction within the private hospitals in Jordan

$\mathrm{H}_{0}$ 3: There is no statistically significant influence of consultation on customer satisfaction within the private hospitals in Jordan.

Table 12. Model summary

\begin{tabular}{lllll}
\hline Model & R & R Square & Adjusted R Square & Std. Error of the Estimate \\
\hline 1 & $.798^{\mathrm{a}}$ & .638 & .637 & .57512 \\
\hline
\end{tabular}

Table 13. Coefficients ${ }^{\mathrm{a}}$

\begin{tabular}{lllllll}
\hline \multirow{2}{*}{ Model } & \multicolumn{2}{l}{ Unstandardized Coefficients } & \multicolumn{2}{l}{$\begin{array}{l}\text { Standardized Coefficients } \\
\text { Beta }\end{array}$} & $\mathrm{t}$ & Sig. \\
& $\mathrm{B}$ & Std. Error & & & \\
\hline 1 & (Constant) & .575 & .112 & & 5.141 & .000 \\
& Consultation & .842 & .031 & .798 & 27.468 & .000 \\
\hline
\end{tabular}


Linear regression is used to test this hypothesis; it was found that $\mathrm{R}(0.798)$ is the correlation of the independent variable and the dependent variable. Also it was found that the t value of (27.468) is significant at (0.05) level. Thus, there is a statistically significant influence of consultation on customer satisfaction within the private hospitals in Jordan.

$\mathrm{H}_{0} 4$ : There is no statistically significant influence of hospitality on customer satisfaction within the private hospitals in Jordan.

Table 14. Model summary

\begin{tabular}{lllll}
\hline Model & R & R Square & Adjusted R Square & Std. Error of the Estimate \\
\hline 1 & $.903^{\mathrm{a}}$ & .816 & .816 & .40960 \\
\hline
\end{tabular}

Table 15. Coefficients ${ }^{\mathrm{a}}$

\begin{tabular}{lllllll}
\hline \multirow{2}{*}{ Model } & \multicolumn{2}{l}{ Unstandardized Coefficients } & \multicolumn{2}{l}{$\begin{array}{l}\text { Standardized Coefficients } \\
\text { Beta }\end{array}$} & $\mathrm{t}$ & Sig. \\
& & $\mathrm{B}$ & Std. Error & & & \\
\hline 1 & (Constant) & .228 & .079 & & 2.902 & .004 \\
& Hospitality & .942 & .022 & .903 & 43.638 & .000 \\
\hline
\end{tabular}

Linear regression was used to test this hypothesis; it was found that $\mathrm{R}(0.903)$ is the correlation of the independent variable and the dependent variable. Also it was found that the t value of (43.638) is significant at (0.05) level. Thus, there is a statistically significant influence of hospitality on customer satisfaction within the private hospitals in Jordan.

$\mathbf{H}_{0}$ 5: There is no statistically significant influence of safe keeping on customer satisfaction within the private hospitals in Jordan.

Table 16. Model summary

\begin{tabular}{lllll}
\hline Model & R & R Square & Adjusted R Square & Std. Error of the Estimate \\
\hline 1 & $.089^{\mathrm{a}}$ & .008 & .006 & .95144 \\
\hline
\end{tabular}

Table 17. Coefficients ${ }^{\mathrm{a}}$

\begin{tabular}{|c|c|c|c|c|c|c|}
\hline \multirow{2}{*}{\multicolumn{2}{|c|}{ Model }} & \multicolumn{2}{|c|}{ Unstandardized Coefficients } & \multirow{2}{*}{$\begin{array}{l}\text { Standardized Coefficients } \\
\text { Beta }\end{array}$} & \multirow[t]{2}{*}{$\mathrm{t}$} & \multirow[t]{2}{*}{ Sig. } \\
\hline & & $\mathrm{B}$ & Std. Error & & & \\
\hline \multirow[t]{2}{*}{1} & (Constant) & 3.392 & .098 & & 34.627 & .000 \\
\hline & Safe Keeping & .064 & .035 & .089 & 1.853 & .065 \\
\hline
\end{tabular}

Linear regression is used to test this hypothesis; it was found that $R(0.089)$ is the correlation of the independent variable and the dependent variable. Also it is found that the $t$ value of (1.853) is not significant at (0.05) level. Thus, there is no statistically significant influence of safe keeping on customer satisfaction within the private hospitals in Jordan.

$\mathbf{H}_{0} 6$ : There is no statistically significant influence of exceptions on customer satisfaction within the private hospitals in Jordan.

Table 18. Model summary

\begin{tabular}{lllll}
\hline Model & R & R Square & Adjusted R Square & Std. Error of the Estimate \\
\hline 1 & $.077^{\mathrm{a}}$ & .006 & .004 & .95240 \\
\hline
\end{tabular}

Table 19. Coefficients ${ }^{\mathrm{a}}$

\begin{tabular}{lllllll}
\hline \multirow{2}{*}{ Model } & \multicolumn{2}{l}{ Unstandardized Coefficients } & \multicolumn{2}{l}{$\begin{array}{l}\text { Standardized Coefficients } \\
\text { Seta }\end{array}$} & $\mathrm{t}$ & Sig. \\
& & $\mathrm{B}$ & Std. Error & Beta & & \\
\hline 1 & (Constant) & 3.426 & .091 & & 37.471 & .000 \\
& Exception & .054 & .034 & .077 & 1.601 & .110 \\
\hline
\end{tabular}


Linear regression was used to test this hypothesis; it was found that $R(0.077)$ is the correlation of the independent variable and the dependent variable. Also it was found that the $t$ value of (1.601) is not significant at $(0.05)$ level. Thus, there is no statistically significant influence of exceptions on customer satisfaction within the private hospitals in Jordan.

$\mathbf{H}_{0}$ 7: There is no statistically significant influence of billing on customer satisfaction within the private hospitals in Jordan.

Table 20. Model summary

\begin{tabular}{lllll}
\hline Model & R & R Square & Adjusted R Square & Std. Error of the Estimate \\
\hline 1 & $.827^{\mathrm{a}}$ & .683 & .683 & .53761 \\
\hline
\end{tabular}

Table 21. Coefficients ${ }^{\mathrm{a}}$

\begin{tabular}{|c|c|c|c|c|c|c|}
\hline \multirow{2}{*}{\multicolumn{2}{|c|}{ Model }} & \multicolumn{2}{|c|}{ Unstandardized Coefficients } & \multirow{2}{*}{$\begin{array}{l}\text { Standardized Coefficients } \\
\text { Beta }\end{array}$} & \multirow[t]{2}{*}{$\mathrm{t}$} & \multirow[t]{2}{*}{ Sig. } \\
\hline & & $\mathrm{B}$ & Std. Error & & & \\
\hline \multirow[t]{2}{*}{1} & (Constant) & .648 & .099 & & 6.551 & .000 \\
\hline & Billing & .822 & .027 & .827 & 30.420 & .000 \\
\hline
\end{tabular}

Linear regression was used to test this hypothesis; it was found that $\mathrm{R}(0.827)$ is the correlation of the independent variable and the dependent variable. Also it is found that the $t$ value of (30.42) is significant at $(0.05)$ level. Thus there is a statistically significant influence of billing on customer satisfaction within the private hospitals in Jordan.

$\mathbf{H}_{0} 8$ : There is no statistically significant influence of payment on customer satisfaction within the private hospitals in Jordan.

Table 22. Model summary

\begin{tabular}{lllll}
\hline Model & R & R Square & Adjusted R Square & Std. Error of the Estimate \\
\hline 1 & $.962^{\mathrm{a}}$ & .925 & .924 & .26225 \\
\hline
\end{tabular}

Table 23. Coefficients ${ }^{\mathrm{a}}$

\begin{tabular}{lllllll}
\hline \multirow{2}{*}{ Model } & \multicolumn{2}{l}{ Unstandardized Coefficients } & \multicolumn{2}{l}{$\begin{array}{l}\text { Standardized Coefficients } \\
\text { Beta }\end{array}$} & $\mathrm{t}$ & Sig. \\
& $\mathrm{B}$ & Std. Error & Bencl & & \\
\hline 1 & (Constant) & .056 & .050 & & 1.132 & .258 \\
& Payment & .997 & .014 & .962 & 72.544 & .000 \\
\hline
\end{tabular}

Linear regression was used to test this hypothesis; it was found that $\mathrm{R}(0.962)$ is the correlation of the independent variable and the dependent variable. Also it was found that the t value of (72.544) is significant at $(0.05)$ level. Thus, there is no statistically significant influence of payment on customer satisfaction within the private hospitals in Jordan.

\section{Discussion}

The current research aimed at understanding the influence of 'flower of service' dimensions on the customer satisfaction within the private hospitals in Jordan. The idea behind the current research sought to examine the level of supplementary services within private hospitals in Jordan and how can the concept of supplementary service influence the satisfaction of customers given that normally what attracts customers of hospitals is the 'core service' the current study sought to examine whether customers were aware of the notion of supplementary service and did it influence their satisfaction?

As it appeared through the analysis that respondents had the needed awareness of the idea of supplementary service and it did influence the way they evaluated the service in the hospital without realizing the difference between core and supplementary service in general; among all eight dimensions of flower of service there appeared (billing and payment) to be the most influential factors that may have a role in increasing or decreasing the satisfaction of customers; it is known that the healthcare services within the private sector in Jordan are very 
expensive and only people who are doing well off in their lives tend to turn to the services of the private sector in issues related to health and healthcare. Based on that, most of the respondents appeared to be influenced with the facilities that the financial department presents for its customers in terms of payments, installments and billings. Edura Wan Rashid and Kamaruzaman Jusoff (2009) noted to the same idea in their study in reference to the financial services in healthcare system as a supplementary service and how it can influence the image of the system among customers arguing that the facilities that a hospital present to their customers in terms of financial issues are one of the items that attracts the attention of customers and increase the level of satisfaction among them. Goyal (2004) indicated that the concept of supplementary services within the financial issues are really important in giving the customer a sense of security and have them feel that they are paying for the service they already used, having the organization planning a well-built financial supplementary service is a key role in avoiding the customers' feelings of paying through the nose which is seen to be a good indicator of a high level service quality. Also, Sadiq Sohail (2003) noted to the fact that finances and financial services in hospitals are among the important approaches to quality services bearing in mind that individuals usually care about money and the value of the services that they get, they expect that better services accompanies more money. On the other hand, Che Rose et al. (2004) including the financial issues within the service quality concept in hospitals is a really challenging managerial task given the increase in the cost of medical tools and equipment within hospitals.

Back to the results of the study, and going through the analysis of the variables and their influence within the responses of the sample of the study it can be seen there appeared a positive influence among respondents towards the variables of (Information, Order Taking, Consultation, Hospitality, Billing and Payment) given that their means were above the scale of (3), however, the variables of (Exception - 2.3237, Safe Keeping- 2.4914) appeared in a negative attitude as the means were below the mean of the scale (3) which indicated that both variables had no influence on the attitude of the sample of the study. This result can be attributed to the fact that people who use the facilities and services of the hospitals normally do not care that much about the issues of exceptions and safe keeping given that the private hospitals are privately owned institutions and normally the services can be reached through paying more money or asking for higher leveled services compared to governmental hospitals which depend on governmental aids from a financial perspective and the support that it receives from the governmental entities which tightens its scheme of services to the degree of important or emergency among customers. In another word, the variables of (safe keeping and exceptions) are seen to be non-routine services which can be reached within the private hospitals through the financial means of customers where those cannot be reached easily within governmental hospitals. On the other hand, it was found out through the results that other dimensions of flower of service do contribute to the satisfaction of customers; on that very same result kumar, Manjunat, K. C (2012) came up in their study arguing that the quality of supplementary services can influence the satisfaction of customers just the same as the core services, and since the flower of service in its overall idea is concerned with the supplementary services it can be concluded that flower of service' dimensions influence the overall satisfaction of customers. On the other hand, Zaim, Bayyurt and Zaim (2010) noted to the idea of the influence of quality of service on the customer satisfaction within hospital and especially private hospitals, the satisfaction in that since can be seen through the differentiation that customers tend to feel between the real service and the expected service. According to Punnakitikashem et al. (2012) paying extra attention to the flow of the flower of service dimensions within the supplementary services within the private hospitals can work as if the hospital is applying a mini system of lean management to its supplementary service which will influence the level of the service that is presented to customers and enhance the level of their satisfaction, it can be looked over as a type of enhancing the service quality in the best way possible without the burden of the managerial complications that can take place.

\section{Conclusion and Recommendations}

The current study aimed at examining the influence of 'flower of service' dimensions on customer satisfaction of the supplementary services within the private hospitals and healthcare givers in Jordan. The sample of the study consisted of (431) individuals who are benefiting from services of private hospitals in Jordan. A self-administered questionnaire was distributed on the sample which consisted of questions regarding the service quality within the private hospitals in Jordan based on the dimensions of 'flower of service'. The results of the study indicated that there is an influence of 'flower of service' dimensions on the satisfaction of customers (Information, Order Taking, Consultation, Hospitality, Billing and Payment) except for (Exception, Safe Keeping). Generally speaking, there appeared a positive influence of customers regarding the dimensions of the flower of service making sure that paying attention to the quality of the supplementary services in organization can influence the satisfaction of its customers and can be seen as an approach to service management given that 
most organizations nowadays are taking much care in increasing the level of the core service on the expense of the supplementary services. As for the beneficiaries of the private hospitals in Jordan; people through the study and the application of the questionnaire have shown a good degree and understanding of the idea of supplementary services and they were able to identify their stand point in regard to the general services that are being presented to them through the private medial sector in Jordan. It is recommended through the study that the management should increase the awareness among its employees of the difference between the supplementary service and the core service and how each one of them is important in its own way. In addition to that, there should be extra care about the importance of service quality which can take place through the awareness that can be spread through the quality control department. Through the analysis, it appeared that payment and billing in addition to hospitality were the most and strongest variables which had an influence on the satisfaction of customers, so it is recommended that -based on respondents' opinion - to increase the level of hospitality within the private hospitals and present more effective payment solutions for patients and their families considering that a person is mainly waiting to be charged in accordance with the service that they get. Also it s recommended that the model could be used in future researched conducted in other service sectors such as: banking sector, insurance sector, etc.

\section{References}

American Marketing Association. (2008). The American Marketing Association Releases New Definition for Marketing. Chicago: American Marketing Association. Retrieved from https://archive.ama.org/archive/AboutAMA/Documents/American\%20Marketing\%20Association\%20Relea ses\%20New\%20Definition\%20for\%20Marketing.pdf

Bitner, M. J., Brown, S. W., \& Meuter, M. L. (2000). Technology Infusion in Service Encounters. Journal of the Academy of Marketing Science, 28(1), 138-149. https://doi.org/10.1177/0092070300281013

Borrego, M., Douglas, E. P., \& Amelink, C. T. (2009). Quantitative, qualitative, and mixed research methods in engineering education. Journal of Engineering Education, 98(1), 53-66. https://doi.org/10.1002/j.2168-9830.2009.tb01005.x

Che Rose, R., Uli, J., Abdul, M., \& Looi Ng, K. (2004). Hospital service quality: A managerial challenge. International Journal of Health Care Quality Assurance, 17(3), 146-159. https://doi.org/10.1108/09526860410532784

Colgate, M., \& Alexander, N. (2002). Benefits and Barriers of Product Augmentation: Retailers and Financial Services. Journal of Marketing Management, 18(1), 105-13. https://doi.org/10.1362/0267257022775927

Edura Wan Rashid, W., \& Kamaruzaman, J. H. (2009). Service quality in health care setting. International Journal of Health Care Quality Assurance, 22(5), 471-482. https://doi.org/10.1108/09526860910975580

Gilaninia, S., \& Nejadjavad, M. (2016). The Role of Service Quality in Organizations. Kuwait Chapter of Arabian Journal of Business and Management Review, 5(7), 19-27. https://doi.org/10.12816/0019403

Goyal, A. (2004). Role of supplementary services in the purchase of credit card services in India. Asia Pacific Journal of Marketing and Logistics, 16(4), 36-51. https://doi.org/10.1108/13555850410765258

Gummesson, E. (2004). Whither Services Marketing. Journal of Services Research, 7(1), 20-41. https://doi.org/10.1177/1094670504266131

Hume, M. (2008). Understanding Core and Peripheral Service Quality in Customer Repurchase of the Performing Arts. Managing Service Quality, 18(4), 349-369. https://doi.org/10.1108/09604520810885608

Kotler, P., \& Dubois, B. (2003). Marketing Management (11th ed.). Pearson Education.

Kotler, P., Bowen, J., \& Makens, J. (2010). Marketing for hospitality and tourism. Boston: Prentice Hall.

Kumar, A., \& Manjunath, K. C. C. (2012). Service Quality At Hospital - A Study Of Apollo Hospital In Mysore. IOSR Journal of Business and Management, 4(1), 1-7. https://doi.org/10.9790/487X-0410107

Levitt, T. (1980). Marketing Success through Differentiation of Anything. Harvard Business Review, 94-102.

Lewis, B., \& Mitchell, V. (1990). Defining and Measuring the Quality of Customer Service. Marketing Intelligence \& Planning, 8(6), 11-17. http://dx.doi.org/10.1108/eum0000000001086

Lovelock, C. (1992). Cultivating the Flower of Service: New ways of Looking at Core and Supplementary Services. In P. Eigler \& E. Langeard (Eds.), Marketing, Operations and Human Resources Insights into Services. Aix-en-Provence, France: Institute d'Administration des Enterprises. 
Lovelock, C. (1995). Competing on Service: Technology and Teamwork in Supplementary Services. Planning Review, (July-August), 32-37. https://doi.org/10.1108/eb054517

Lovelock, C., \& Wirtz, J. (2016). Services marketing. Hackensack: World Scientific.

Lovelock, C., Patterson, P. G., \& Wirz, J. (2011). Services Marketing: An Asia-Pacific and Australasian Perspective. Frenchs Forest, NSW: Pearson Australia.

Major, B., McLeay, F., \&Waine, D. (2010). Perfect Weddings Abroad. Journal of Vacation Marketing, 16(3), 249-262. https://doi.org/10.1177/1356766710372242

Naipaul, S., \& Parsa, H. G. (2000). Supplementary Services as a Differentiation Strategy: An Empirical Investigation of Lovelock's Model in Tourism. Journal of Quality Assurance in Hospitality \& Tourism, 1(1), 67-80. https://doi.org/10.1300/J162v01n01_05

Punnakitikashem, P., Buavaraporn, N., Maluesri, P., \& Leelartapin, K. (2012). Health Care Service Quality: Case Example of a Hospital with Lean Implementation. POMS 23 rd Annual Conference, Chicago, Illinois.

Punnakitikashem, P., Buavaraporn, N., Maluesri, P., \& Leelartapin, K. (2012). Health Care Service Quality: Case Example of a Hospital with Lean Implementation. Health Care Service Quality, 20(23).

Sadiq, S. M. (2003). Service quality in hospitals: More favorable than you might think. Managing Service Quality: An International Journal, 13(3), 197-206. https://doi.org/10.1108/09604520310476463

Storey, C., \& Easingwood, C. J. (1998). The Augmented Service Offering: A Conceptualization and Study of Its Impact on New Service Success. Journal of Product Innovation Management, 15, 335-351. https://doi.org/10.1016/S0737-6782(97)00107-0

Sukamolson, S. (2006). Fundamentals of quantitative research. Chulalongkorn University.

Zaim, H., Bayyurt, N., \& Zaim, S. (2010). Service Quality and Determinants of Customer Satisfaction in Hospitals: Turkish Experience. International Business \& Economics Research Journal, 9(5), 51-58.

Zalaghi, H., \& Khazaei, M., 2016. The Role of Deductive and Inductive Reasoning in Accounting Research and Standard Setting. Asian Journal of Finance \& Accounting, 8(1), 23-37. https://doi.org/10.5296/ajfa.v8i1.8148

\section{Copyrights}

Copyright for this article is retained by the author(s), with first publication rights granted to the journal.

This is an open-access article distributed under the terms and conditions of the Creative Commons Attribution license (http://creativecommons.org/licenses/by/4.0/). 